\title{
The Financial Markets' Response to Covid-19: A Review
}

\author{
Mushtaque Ahmed Laghari ${ }^{1}$; Huidan $\mathrm{Xu}^{2}$ \\ ${ }^{1}$ College of Economics, Sichuan Agricultural University, Chengdu, Sichuan, 611130, China \\ ${ }^{2}$ College of Economics, Sichuan Agricultural University, Chengdu, China \\ Correspondence: College of Economics, Sichuan Agricultural University, Chengdu, Sichuan, China \\ E-mail: xuhd@sicau.edu.cn
}

http://dx.doi.org/10.47814/ijssrr.v5i3.230

\begin{abstract}
From the beginning of 2020, Covid-19 has severely affected the world by its impulsive and deadly outburst. Due to its multiple hazardous effects, many scholars have attempted to address how the viral disease has influenced financial markets of both developed and under developing countries. The research problem interpreted by this paper is the actual impact that the pandemic has left on global financial markets. It is sensible to conclude that Covid-19 has left a huge impact on the financial markets and the economic sector worldwide. From the data reviewed, it is evident that there is an actual correlation between the pandemic and the fall of financial markets. This research has used qualitative and quantitative methods to address the topic, and has brought forth a concise summary of the epidemic's effect. All countries, industrialised or developing, have felt the economic pressure that has been raised with the outbreak of Covid-19.
\end{abstract}

Keywords: Covid-19; Financial Markets; Review; Impact

\section{Introduction}

The COVID-19 epidemic (earlier 2019-nCoV) was originated by the SARS-CoV-2 infection. This epidemic was held on December 2019 in Wuhan city in Hubei county of China. Corona virus keeps on spreading over the world. As a global crisis, covid-19 has greatly affected the economies of different countries. With the spread of the diseases, the share market prices have been reported to fall rapidly. The pandemic was unforeseen, which means that the global economy was not prepared beforehand to cope with it. Resultantly, it has left effects that most researchers have come up to explain in their articles. Every scholar has their opinion regarding the matter but most of them seem to agree that it has negatively impacted the financial markets. Some argue that the effect is more severe in developing countries while others assert that the impact is the same across all states in the world. Although the pandemic has not yet been overcome, this review will show the progress that has been made in literature regarding Covid-19 and its effects on financial markets. 


\section{Literature Review}

This section goes ahead to review the literature of other scholars as support in order to validate any claims made in the research. (Gururangan, 2020) seeks to illustrate the impact that Covid-19 has left on the financial markets of developing countries. They claim that such countries have been hit the hardest in the economic sector. Even as share prices reduce, every country is needed to have enough resources to afford the measures put in place against Covid-19. Similarly, (Haber, 2020) backs the idea up with even more specific examples. They state that Kenya, which is a leading coffee producer in the world, has experienced economic stagnation over the last few months of the pandemic.

(Admin, 2020), on the other hand, addresses the topic from the examples of 2 developed countries, China and USA. They make the affirmation that Covid-19 has brought negative change to the economic world. To support their reasoning, they pick two widely known monopolies, the Dow and S\&P, and assess their performance after the pandemic. They find that within a day, the Dow and S\&P had made their biggest fall since 1987. In response, policymakers in Washington were prompted to develop an economic rescue plan. (Hanc, 2020) provides a clear argument on the effect of covid-19 to the commercial markets and banks. They use the example of the reduction of shares and oil, among other things, all over the world. They, therefore, claim that it is only after this pandemic that a decrease was noted in any of the above-mentioned sectors. (Hudson, 2020) comes with more evidence that backs up the assertion that Covid-19 impacted financial markets greatly and significantly. The reviewed scholar mentions the fact that trillions of money have been lost in response to this pandemic, and most asset classes have since then pursued safety. The quality masks and sanitizers recommended to everyone have been priced differently, and some people find them unaffordable ( $\mathrm{Hu}$, Yang, Li \& Huang, 2020). Most governments have, thus, taken the initiative to provide these product at a lower cost, which has significantly hurt the economy.

(Davis \& Lohm, 2020) addresses the possibility of fixing the economy that covid-19 has broken. Huge as the impact is, the resolution would need to be thought out carefully. Returning fuel prices to the norm cannot happen in the flash of a second, not at this time. It would, thus, take a strategic move by all governments to cub the effects of the pandemic on the economy. (Klein,2020) refers to the process of healing the economy as a 'massive move.' They mean that it is a delicate matter and can only be handled right with a strategic approach. The two scholars show that Covid-19 will be overcome, and the financial markets will rise again but all this will take time.

(Koley\& Dhole, 2020) blame the deteriorating economy on the expensive measures to curb the spread of Covid-19. They assume that the financial markets would be at a good place if there weren't all these economically unfriendly requirements that are meant to prevent the spread of the infection. (Jhaveri,2020), on the other hand, disagrees with such claims arguing that the measures are only for the good of people's health. Even so, they agree on the fact that Covid-19 has reduced negatively influenced financial markets.

(Linton, 2020) narrows their interest down to businesses and companies. They elucidate how the pandemic has affected different organizations by lowering their sales while increasing their costs for production. With decreased sales, an organization is only obliged to work at higher rates to gain the profit back. (Mukherjee, 2020) agrees with the author's assertion and proceeds to give further examples. They state that the pandemic has significantly put certain businesses down, and they are left with no choice but to waver their prices. When market prices go high, there must be a corresponding down pull of the economy.

(Sansa, 2020) lists The Dow Jones and S\&Pof the United States as examples of falling markets consequent to the pandemic, which will be discussed in detail. They proceed to use Nikkei as another 


\section{International Journal of Social Science Research and Review}

illustration of the impact of covid-19 on share prices. They first recall that Nikkei does stock exchange with Tokyo, then state how its share prices recorded a continuous decrease as Covid-19 spread overtime. In response to the shock that has hit the world economy; various huge banks have taken the step to demand a reduction in emergency interest rates (Raikar, 2020). The main stock markets globally got affected by the epidemic from as early as February. Resultantly, trades such as travel and relaxation, food and catering, among others, fell victim to the same.

(Roe, 2020) further excludes China from the countries whose financial markets have been affected by the pandemic. They affirm that China remains stable economically despite the hard-hitting global menace affecting other countries. At this point, the author indicates their objective and significance of this study, stating that they wish to create new awareness regarding the impact of covid-19 on financial markets. Similarly, (Tang \& Li, 2020) state that such information would be useful to the governments of the affected countries as it will help them make relevant future plans. Lastly, (Smith, 2020) is confident that the information they share will be learn as part of the Economics Major for future reference.

\section{Materials and Methods}

This part of the paper explains the choice of methodology for the research. As earlier indicated, qualitative research is employed to draw valid results on the impact of the pandemic on different financial markets. Different markets from diverse countries are assessed, and some financial institutions interviewed to develop a clear understanding of this effect. For the quantitative analysis, the number of currently confirmed cases of the virus is used and weighed against the consistency of the financial markets of those countries. For the industrialized countries, New York Dow Jones and Shanghai will be the markets assessed.

On the other hand, for the developing countries, a direct questionnaire was submitted and answered by one of the industrialists in an African country, Kenya to be precise. Their response on how the pandemic has affected the stock markets of their country was weighed against the number of confirmed corona virus cases in the same place. With these forms of methodology, clear and concise results were obtained.

\section{Results}

\begin{tabular}{|c|c|c|c|}
\hline $\begin{array}{c}\text { No. of Cases for 5 days } \\
\text { (March } \mathbf{1}^{\text {st }} \text { - March } \mathbf{5}^{\text {th }} \text { ) }\end{array}$ & $\begin{array}{c}\text { Kenya } \\
\text { (Developing Country) }\end{array}$ & $\begin{array}{c}\text { USA } \\
\text { (Developed Country) }\end{array}$ & $\begin{array}{c}\text { China } \\
\text { (Developed country) }\end{array}$ \\
\hline 1st & 4 & 70 & 79826 \\
\hline $\mathbf{2 n d}^{\text {rd }}$ & 7 & 75 & 80028 \\
\hline $\mathbf{3}^{\text {th }}$ & 10 & 100 & 80151 \\
\hline & 14 & 122 & 80270 \\
\hline
\end{tabular}

Figure 1. 


\begin{tabular}{|c|c|c|c|}
\hline $\begin{array}{c}\text { Date From March } 1^{\text {st }} \text { to } \\
\text { March } 5^{\text {th }}\end{array}$ & $\begin{array}{c}\text { Kenya } \\
\text { (Stock market) }\end{array}$ & $\begin{array}{c}\text { USA(Dow) } \\
\text { (Stock Market) }\end{array}$ & $\begin{array}{c}\text { CHINA(Shanghai) } \\
\text { (Stock Market) }\end{array}$ \\
\hline $1^{\text {st }}$ & 653 & 25910 & 2982 \\
\hline $2^{\text {nd }}$ & 653 & 25910 & 2982 \\
\hline $3^{\text {rd }}$ & 700 & 26000 & 2998 \\
\hline $4^{\text {th }}$ & 721 & 26361 & 3002 \\
\hline
\end{tabular}

Figure 2.

Starting with the China Shanghai Stock Exchange market, the results disclose a notable relationship between the market and the spread of Covid-19. This shows that for every increase in the number of positive cases of the pandemic, there is a significant change in the Shanghai Stock Markets. The statistics also prove that there is a similar case for the correlation between Covid-19 and the USA New York Dow Jones. The data on the stock market numbers for US and China was obtained from (Sansa, 2020) while the data for Kenya was obtained from Mr Smurf of the Commercial Bank of Kenya.

Regarding the qualitative analysis, the interview with an industrialist from Kenya, a developing country, indicated a noteworthy difference in the market prices and the overall economy after covid-19. They stated that their own businesses got affected in many ways, and they have had to waver their prices to record some profit. The industrialist in question, Mr Smurf, is a commercial bank shareholder, and they noted that with the current financial crisis, the annual interest on money reduced. As a result, most people have withdrawn their interest-worthy money from the bank which has an overall negative effect on the share markets.

\section{Discussion \& Conclusion}

Various monetary organizations have alerted the world beforehand that Covid-19 may leave a bigger economic crisis than the one that was observed in 2007-2008. It is important to note that the world has already been affected in many ways financially, to the point that a good number of people can no longer afford the expenses for their basic needs. Economic experts, as the article states, have foreseen a negative impact of the pandemic not only on financial markets but also on social welfare and the economy in general. Importation and exportation, for instance, have already been influenced by the epidemic enormously. Most countries across the world have set strict measures around buying or selling from other countries, restricting either of the practices in some cases. There are countries whose economies are held majorly by the value of their exportation. If a state was known widely for its production of a certain product, most other countries choose to import the product from it. With the rise of covid-19, however, such a country would only get disappointed when they can no longer make their exportations with ease.

It is reasonable to conclude at this time that Covid-19 seems to have a significant impact on the financial markets and the economy overall. According to the data analysis, there is a direct link between the pandemic and the downfall of financial markets. This research collected information on the topic using both qualitative and quantitative methodologies, and it produced a short assessment of the 
epidemic's impact. The economic pressure which has increased since the emergence of Covid-19 has been observed by all countries, advanced and emerging. The articles evaluated in this research demonstrate that the financial markets are not the same as they were prior to the pandemic.

\section{References}

Admin, S. (2020). Annual Reviews: Coronavirus Research. doi:10.14293/s2199-1006.1.sormed.clwwgpn.v1

Davis, M., \&Lohm, D. (2020). Pandemic Tales. Pandemics, Publics, and Narrative, 22-45. doi:10.1093/oso/9780190683764.003.0002

Gururangan, K. (2020). Review 2: "Neurological manifestations associated with COVID-19: A nationwide registry". Rapid Reviews COVID-19. doi:10.21428/2e3983f5.b229343e

Haber, N. (2020). Review 1: "Preprinting a pandemic: The role of preprints in the COVID-19 pandemic". Rapid Reviews COVID-19. doi:10.21428/2e3983f5.ee267763

Hanc, O. (2020). Theological and practical challenges in the Covid-19 pandemic. Proceedings of DIALOGO-CONF 2020. doi:10.18638/dialogo.2020.6.2.19

He, S., \& Smith, E. (2020). Review 2: "Preprinting a pandemic: The role of preprints in the COVID-19 pandemic". Rapid Reviews COVID-19. doi:10.21428/2e3983f5.716acfed

Hu, Z., Yang, Z., Li, Q., \& Huang, Y. (2020). Nomenclature: Coronavirus and the 2019 Novel Coronavirus. doi:10.20944/preprints202002.0380.v1

Hudson, D. S. (2020). The economic, social and environmental impacts of COVID 19. COVID-19 and Travel. doi:10.23912/9781911635703-4429

Introduction. (2020). Iscayahl 2020. doi:10.1055/s-0040-1701867

Jeronimus, B. (2020). Personality and Coronavirus 2019 Pandemic. doi:10.21827/5ed9ebc01d65f

Jhaveri, R. (2020). Echoes of 2009 H1N1 Influenza Pandemic in the COVID Pandemic. Clinical Therapeutics, 42(5), 736-740. doi:10.1016/j.clinthera.2020.04.003

Klein, S. (2020). Assessment of the CDC's New COVID-19 Data Reporting. Coronavirus Concordance. doi:10.21428/85acfa8f.54acf4dd

Koley, T. K., \& Dhole, M. (2020). Pandemic. The COVID-19 Pandemic, 7-22. doi:10.4324/9781003095590-2

Linton, O. (2020). When will the Covid-19 pandemic peak? doi:10.1920/wp.cem.2020.1120

Mukherjee, A. P. (2020). COVID-19 Safety Tips - Советыпобезопасности COVID-19 (English + Russian). doi:10.31219/osf.io/dt45z

Raikar, S., \& Adamson, S. (2020). Basic project finance concepts. Renewable Energy Finance, 21-29. doi:10.1016/b978-0-12-816441-9.00003-9 
Roe, K. (2020). COVID-19 infection thrombosis due to hemagluttination of antibodies and COVID-19 antigens bound to erythrocytes. doi:10.22541/au.158872328.86968358

Sansa, N.A (2020) "The Impact of Covid-19 on the financial markets: Evidence from China and USA", Electronic Research Journal of Social Sciences and Humanities ISSN: 2706-8242 https://www.researchgate.net/publication/340771886_The_Impact_of_the_COVID_19_on_the_Financial_Markets_Evidence_from_China_and_USA

Smith, K. (2020). Coronavirus Treatment: Eradicate Coronavirus by blocking replication, counteracting its defensesystem\&nbsp;\&nbsp;\&nbsp;\&nbsp;. doi:10.22541/au.159654499.92297223

Tang, Y., \& Li, C. (2020). Review 1: "Neurological manifestations associated with COVID-19: A nationwide registry". Rapid Reviews COVID-19. doi:10.21428/2e3983f5.95a6c65e

\section{Copyrights}

Copyright for this article is retained by the author(s), with first publication rights granted to the journal.

This is an open-access article distributed under the terms and conditions of the Creative Commons Attribution license (http://creativecommons.org/licenses/by/4.0/). 